Article

\title{
Spatial Patterns of Irradiance and Advanced Reproduction along a Canopy Disturbance Severity Gradient in an Upland Hardwood Stand
}

\author{
Amanda M. Keasberry ${ }^{1}$, Justin L. Hart ${ }^{1, *}$, Daniel C. Dey ${ }^{2}$ and Callie J. Schweitzer ${ }^{3}$ \\ 1 Department of Geography, University of Alabama, Tuscaloosa, AL 35487, USA; \\ amkeasberry@crimson.ua.edu \\ 2 Northern Research Station, USDA Forest Service, Columbia, MO 65211, USA; ddey@fs.fed.us \\ 3 Southern Research Station, USDA Forest Service, Huntsville, AL 35801, USA; cschweitzer@fs.fed.us \\ * Correspondence: hart013@ua.edu; Tel.: +1-205-348-1673
}

Academic Editor: Timothy A. Martin

Received: 7 January 2016; Accepted: 18 March 2016; Published: 24 March 2016

\begin{abstract}
Regeneration failure of Quercus in mature Quercus-dominated forests has been reported throughout the temperate zone. Quercus seedlings are often abundant in these forests, yet frequently fail to recruit to larger size classes despite canopy disturbances. To examine intra-stand patterns of advanced reproduction, competition, and irradiance in an upland Quercus stand, we installed a 2 ha plot that captured the canopy disturbance severity gradient caused by a wind event. To quantify disturbance severity and stand conditions, we inventoried all living and dead woody stems $\geqslant 5 \mathrm{~cm}$ diameter at breast height ( $\mathrm{dbh}, 1.37 \mathrm{~m}$ above the surface) and quantified irradiance in $25 \mathrm{~m}^{2}$ quadrats $(n=800)$ using synchronized ceptometers. To inventory patterns of advanced reproduction within the plot, we recorded the species of every woody stem $>1 \mathrm{~m}$ in height and $<5 \mathrm{~cm} \mathrm{dbh}$. We also documented the species and height of every Quercus stem $\geqslant 0.5-<5 \mathrm{~cm}$ dbh and the species, height, and distance to each stem nearest the focal Quercus stem. At the genus-level, Quercus was the most common nearest neighbor. However, at the species-level, the most common nearest neighbors were Acer saccharum and Ostrya virginiana. Competition index values significantly differed by species $(p<0.01)$, but did not significantly differ by disturbance severity class and we found no significant interactions between species and disturbance class. Quercus advanced reproduction was significantly clustered through the study plot and cluster locations overlapped with clusters of high irradiance, but these patterns were scale-dependent. Our results indicate that an appreciation for intra-stand heterogeneity may improve forest management planning.
\end{abstract}

Keywords: competition; oak (Quercus); photosynthetically active radiation (PAR); wind disturbance

\section{Introduction}

Quercus species are widespread throughout the northern hemisphere and reach their highest levels of diversity and endemism in North America [1]. Indeed, in the eastern United States the landscape is characterized by forests either dominated by Quercus or in which Quercus is a component [2-4]. Paleoecological analyses indicate that Quercus has been the dominant genus in forests of this region throughout much of the Holocene [5-7]. However, a widespread pattern of forest composition change is evident throughout the eastern United States. Quercus regeneration failure has been reported in Quercus-dominated systems across a range of site types throughout the region. The sapling and small-tree size classes in many Quercus stands are devoid of Quercus stems and are instead comprised of species with greater shade-tolerance, especially Acer rubrum L. and Acer saccharum Marsh. [8-10]. This phenomenon is not restricted to North America as it has also been observed in Europe and 
Asia [11-14]. Based on the abundance of quantitative data reported from Quercus stands in the eastern United States, many researchers have concluded that this pervasive composition change from Quercus-to-Acer is inevitable over millions of hectares [15-18]. Unequivocally, the replacement of Quercus by more shade-tolerant species will present challenges to the management of wildlife populations, forest commodities, and other ecosystem goods and services [19-21].

Quercus seedlings are often abundant in mature Quercus-dominated stands, but these seedlings typically fail to recruit to sapling and small-tree size classes even following canopy disturbances that modify the sub-canopy radiation regime [22-26]. This phenomenon has been documented in stands throughout the eastern United States (e.g., [27-30]). The sapling and small-tree size classes in these stands often support an abundance of shade-tolerant stems which restrict insolation to Quercus seedlings and inhibit Quercus regeneration [22,31-33].

Canopy disturbance and subsequent increases in the quantity and quality of understory insolation is critical for the regeneration of Quercus [25,34]. Without receiving increased photosynthetically active radiation (PAR), Quercus seedlings are not able to recruit to the sapling size class and mortality rates are high (referred to as the Quercus bottleneck). Thus, silvicultural systems in Quercus stands are largely developed to modify the light regime [35,36]. In Quercus stands with an abundance of shade-tolerant trees in sub-canopy strata, increased light caused by canopy disturbance may be restricted from reaching Quercus seedlings near the forest floor. As canopy disturbance is required for Quercus regeneration, Quercus advanced reproduction in stands may exhibit clumped or clustered patterns as a result of current or former canopy openings [14,37]. By using stand-level averages of metrics such as basal area and stem density, intra-stand spatial patterns, which can be highly variable, may not be revealed. Adjusting our management approach to account for intra-stand spatial variability requires the reevaluation of the stand concept [38-40]. Natural disturbances can create variable patches because of temporal variation in disturbance intensity, local variation in tree size, species susceptibility, and topographic variations among other factors [41-45].

Studies conducted at multiple spatial scales where size (i.e., size of the observational unit) and extent (i.e., size of the entire study area; [46]) are independent of one another may identify the best resolutions of domains, patterns, and the determinants of the relationships among spatial scales. We used a continuous plot sampled at a fine-spatial resolution $(5 \times 5 \mathrm{~m})$ in attempt to elucidate the mechanisms (competition and PAR) that drive the variable patterns of Quercus advanced regeneration after a disturbance at the intra-stand level. The data set provided an opportunity to evaluate the spatial relationships of Quercus spp. and neighboring stems (labeled competitors in our analysis) along a canopy disturbance severity gradient with a modified sub-canopy light regime. This information is useful to further our understanding of competition in the regeneration layer and the potential relationships between stems and irradiance; information which is needed to develop a mechanistic understanding of the widespread pattern of Quercus regeneration failure. The specific objectives of this study were to: (1) document the species, height, and distance of all stems nearest Quercus advanced reproduction to provide information on competition dynamics in the regeneration layer; (2) quantify spatial patterns of irradiance in the understory; and (3) analyze spatial patterns of Quercus advanced reproduction, competition in the regeneration layer, and understory irradiance at multiple spatial scales along a canopy disturbance gradient. We hypothesized that Quercus advanced reproduction would be clustered rather than uniform throughout the plot and that clustering would be related to irradiance levels and/or density of competing non-Quercus stems. Our results have implications for the consideration of intra-stand silvicultural approaches to Quercus regeneration as our findings highlight spatial variability of advanced reproduction in Quercus stands. 


\section{Study Area and Methods}

\subsection{Study Area}

Our study was conducted in the Sipsey Wilderness $\left(34^{\circ} 20^{\prime} \mathrm{N}, 87^{\circ} 25^{\prime} \mathrm{W}\right)$ on the William B. Bankhead National Forest in Alabama, USA. The Sipsey Wilderness is a 10,085 ha reserve managed by the USDA Forest Service. The reserve is located on the southern Cumberland Plateau section of the Appalachian Plateaus physiographic province [47]. Pennsylvanian Pottsville formation bedrock underlies this region and the geology is predominantly comprised of sandstone with lesser amounts of siltstone, varying levels of stratified shale, and thin layers of discontinuous coal [48,49]. The southern Cumberland Plateau is strongly dissected and is characterized by complex topography [47]. Regionally, soils are coarse to medium textured, somewhat shallow, well to excessively drained, and typically acidic [50].

The regional climate is humid mesothermal characterized by long, hot summers and short, mild winters [51]. The mean annual temperature is $16{ }^{\circ} \mathrm{C}$ (January mean: $5{ }^{\circ} \mathrm{C}$; July mean: $26{ }^{\circ} \mathrm{C}$ ) and the frost-free period spans approximately 220 days from late-March to early-November [52]. Precipitation rates are evenly distributed throughout the year with no distinct dry season. Mean annual precipitation is $1390 \mathrm{~mm}$ with a January average of $135 \mathrm{~mm}$ and a July average of $113 \mathrm{~mm}$ [52]. Thunderstorms occur on average 75 days. year ${ }^{-1}$ and result from convective lifting and low-pressure centers [53].

Based on Braun's [54] forest classification, the southern Cumberland Plateau region represents a transitional zone between the Mixed Mesophytic Forest Region to the north and the Quercus-Pinus Forest Region to the south. Forest communities on the Cumberland Plateau are noted for high species richness and species composition is strongly influenced by topography and soil water availability [55,56]. Zhang et al. [57] classified 14 ecological communities based on dominant overstory species throughout the Sipsey Wilderness. Ridges and upper slope positions are often dominated by Pinus taeda L. and Pinus echinata Mill. Over a distance of less than $100 \mathrm{~m}$ along a topographic gradient, stands may transition to support stronger components of hardwood species [57,58]. Middle and lower slope positions are characterized by mesic hardwood stands that include components of Fagus grandifolia Ehrh., Liriodendron tulipifera L., and Magnolia macrophylla Michx. [58-60]. Zhang et al. [57] found that Quercus was the most abundant genus in the Sipsey Wilderness and occurred in almost all 14 delineated community types.

On 20 April 2011 a long-lived, quasi-linear convective system developed in the region [61]. The system produced an EF1 tornado that tracked $c a .5 \mathrm{~km}$ and directly damaged portions of the Sipsey Wilderness. Wind gusts of $152 \mathrm{~km} \cdot \mathrm{h}^{-1}$ were recorded within a subsequent wake low system. Storm damage was most severe in the tornado path and decreased in severity of disturbance with distance from the main storm track $[62,63]$. Windstorms of this severity occur frequently in the middle-west and southeast region of the United States [64].

\subsection{Field Methods}

Data were collected in summer 2014 during the fourth growing season post-disturbance. We established a 2 ha $(100 \mathrm{~m} \times 200 \mathrm{~m})$ permanently marked rectangular plot within a single stand that met the following criteria: (1) Quercus alba L. dominated; (2) fully contained within the Sipsey Wilderness; (3) establishment date circa 1900; (4) directly influenced by the April 2011 tornado; and (5) without official records or observations indicating past anthropogenic disturbances affecting stand development. Candidate stands were located using geo-referenced data provided by the USDA Forest Service, data from previous studies in the area $[60,62,63]$, and field reconnaissance. The plot location was determined in situ with the use of topographic maps and visual reconnaissance. The plot was established in a location to minimize topographic variation (3.7\% slope) and provide at least a $25 \mathrm{~m}$ buffer from adjacent stands to avoid immediate changes in environmental factors and species composition. The long axis of the plot was oriented perpendicular to the swath of the tornado to incorporate varying magnitudes of canopy disturbance resulting from the storm so we could collect an 
inventory of post-disturbance conditions across the full canopy disturbance gradient (i.e., from the middle of the tornado track to undisturbed portions of the stand).

The 2 ha plot was subdivided into $5 \times 5 \mathrm{~m}$ quadrats $(n=800)$ to allow for analyses at a fine spatial resolution. In each quadrat we recorded species and diameter at breast height (dbh) of every live stem $\geqslant 5 \mathrm{~cm} \mathrm{dbh}$. Dead stems ( $\geqslant 5 \mathrm{~cm} \mathrm{dbh}$ ) rooted within the plot were measured for diameter at $1.37 \mathrm{~m}$ above the root collar (estimated standing dbh), classified to the lowest taxonomic level possible, and categorized as snag, uprooted, or snapped stem [60,65].

Dead stems were placed into a decay class to determine the amount of basal area removed by the windstorm event. Decay classification was based on Fraver et al. [66] and included decay class 1 (wood was sound, bark was intact, small to medium branches were still present); decay class 2 (wood was sound to slightly rotten, bark maybe attached, large branch stubs were present, log maintained round shape); decay class 3 (wood was substantially rotten, wood texture was moist, bark was barely attached, bole was oval shaped and partially buried in duff); decay class 4 (wood was rotten, branch stubs rotted, bark was detached, log was oval shaped and largely buried by duff).

In each quadrat, all living saplings $\geqslant 1 \mathrm{~m}$ height, $<5 \mathrm{~cm}$ dbh were tallied by species and placed into one of four height classes ( $A=1-2 \mathrm{~m}$ height; $B=2-3 \mathrm{~m}$ height; $C=3-4 \mathrm{~m}$ height; $\mathrm{D}=4 \mathrm{~m}$ height $-<5 \mathrm{~cm}$ $\mathrm{dbh}$ ). For all Quercus stems $\geqslant 0.5 \mathrm{~m}$ height and $<5 \mathrm{~cm}$ dbh (hereafter referred to as small-sized Quercus stems), we measured the stem height and documented the species. For each of these Quercus stems, we also documented the distance, stem height, and species of the nearest neighboring stem $\geqslant 0.5 \mathrm{~m}$ height, $<5 \mathrm{~cm}$ dbh within each quadrat. The Quercus nearest neighbor had no qualification besides being alive, woody, proximity, and size. Quercus stems $<0.5 \mathrm{~m}$ were not analyzed because they are often poor competitors attributed to slow shoot growth and have high mortality rates [67]. Quercus seedlings may fail to recruit after canopy disturbance if they are shorter than surrounding stems. Thus, we focused on small-sized Quercus stems that had a higher probability of being competitive after a canopy disturbance. At these heights, the Quercus stems and neighboring stems were directly competing (crowns touching sensu [68]) or in such close proximity so that Quercus have the ability to obtain or maintain a competitive advantage if conditions are suitable $[69,70]$.

Photosynthetically active radiation $\left(\mu \mathrm{mol} \cdot \mathrm{m}^{-2} \cdot \mathrm{s}^{-1}\right)$ was measured with two synchronized ceptometers (AccuPAR LP-80, Decagon Devices, Pullman, WA, USA) to quantify the understory radiation regime. One ceptometer was placed in full sunlight, while the second simultaneously recorded PAR levels within each $5 \times 5 \mathrm{~m}$ quadrat at $1.37 \mathrm{~m}$ above the surface (i.e., breast height). The quadrat ceptometer measurements were taken in a logarithmic spiral pattern (80 total readings per quadrat), starting at the center of the quadrat and spiraling outward to the edge. The 80 readings for each quadrat were averaged to provide a singular value. The mean quadrat value was divided by the readings simultaneously collected from the full sun ceptometer and converted to determine the percent of full sunlight for each of the 800 quadrats.

\subsection{Analytical Methods}

All live stems $\geqslant 5 \mathrm{~cm}$ dbh were analyzed using standard descriptors. We calculated frequency (number of quadrats present), relative frequency (percent of quadrats present), density (number of stems ha ${ }^{-1}$ ), relative density (contribution to total trees), dominance (basal area $\left(\mathrm{m}^{2} \cdot \mathrm{ha}^{-1}\right)$ ), relative dominance (contribution to total basal area), and relative importance (average of relative density and relative dominance) of each species. For saplings we calculated density at three spatial resolutions $(5 \times 5 \mathrm{~m}, 10 \times 10 \mathrm{~m}, 20 \times 20 \mathrm{~m})$ to identify the spatial patterns of the stems to determine the scale at which these patterns manifested (clumped, regular, or random distributions).

Based on the time since canopy disturbance, we assumed that trees killed by the April 2011 storm event were in decay class I [62]. To assess the gradient of canopy disturbance, we categorized damage severities by averaging basal area lost over a $20 \times 20 \mathrm{~m}$ area. This spatial resolution was chosen based on the Krajicek et al. [71] maximum crown width equation for Quercus spp. in the Central Hardwood Region of the United States. The maximum crown width of the largest decay class I Q. alba 
stem was $17 \mathrm{~m}$. Therefore, we deemed $20 \times 20 \mathrm{~m}$ an appropriate size to classify damage severity based on the potential extent of damage resulting from the windthrown tree. The average amount of basal area removed (i.e., trees killed) from the natural mortality of individual trees (sensu [72]) in the control plots was used as a surrogate for background mortality in study stands within the Sipsey Wilderness. This value was acquired from Cowden et al. [62] from data collected in this and adjacent stands within the Sipsey Wilderness. To account for downed trees post-disturbance, we subtracted the background rate of mortality, which was calculated as the average basal area $\left(\mathrm{m}^{2}\right)$ lost from control plots, from the basal area lost in each $20 \times 20 \mathrm{~m}$ plot to estimate the basal area removed (decay class 1 stems/live stems + decay class 1 ) by the moderate-severity disturbance event. We then used the estimate of basal area removed by the April 2011 storm event to categorize each $20 \times 20 \mathrm{~m}$ plot into one of four disturbance class neighborhoods following the criteria of Hanson and Lorimer [44]: control $=0 \%-10 \%$ basal area removed, light disturbance $=11 \%-30 \%$ basal area removed, moderate disturbance $=31 \%-60 \%$ basal area removed, and severe disturbance $\geqslant 60 \%$ basal area removed. The control neighborhoods (i.e., undamaged areas) were assumed to be representative of pre-disturbance conditions using a space-for-time substitution (Figure 1).

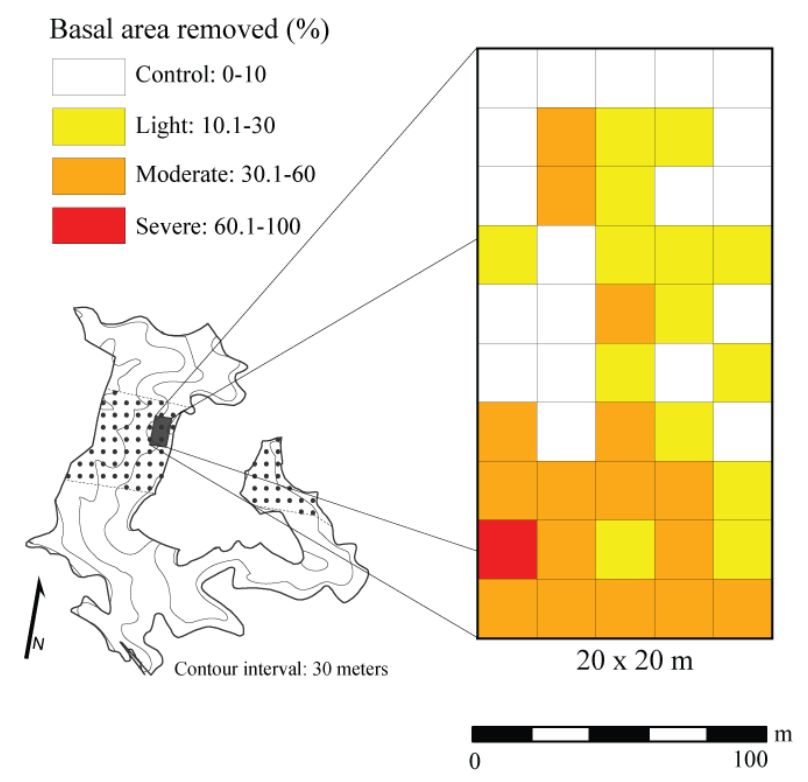

Figure 1. Spatial distribution of disturbance classes in a 2 ha plot based on estimated basal area removed by a wind event in a Quercus dominated stand within the Sipsey Wilderness, Alabama, USA. Inset map shows the Quercus stand boundary, tornado swath (dotted pattern), plot location, and topography.

We used Hegyi's [73] distance-weighted competitor index:

$$
\mathrm{CI} i=\frac{\frac{h j}{h i}}{\text { DIST } i j}
$$

where

$$
\begin{aligned}
\mathrm{CI} i=\text { competition index } & \text { of the } i t h \text { focal tree, } h j=\text { height of competitor stem, } h i \\
& =\text { height of focal stem, DIST } i j \\
& =\text { distance between focal tree we and the } j t h \text { competitor }
\end{aligned}
$$

to analyze the competitive ability of the small-sized Quercus stem's nearest neighbor on the focal Quercus stem [74-77]. All statistical analyses were performed in SAS version 9.4 (Cary, NC, USA). Data 
used for the comparison of means were statistically analyzed and visually assessed for normality and homoscedasticity. Variables that did not meet these criteria were log-, square root- or rank-transformed. To examine significant differences among the three disturbance classifications (i.e., light, moderate, and severe disturbance neighborhoods), one-way analysis of variance (ANOVA) was performed for Quercus stem height, nearest neighbor height, number of Quercus per quadrat, number of primary nearest neighbor stems per quadrat (i.e., the most commonly occurring nearest neighbor species: A. saccharum and Ostrya virginiana (Mill.) K. Koch.), and percent full sunlight. If a statistically significant difference was found among the four disturbance classes $(p<0.05)$, a Tukey-Kramer post-hoc test was conducted to identify which groups were different. Pearson correlation tests were used to assess the relationships between the Quercus stem height, nearest neighbor height, and distance from Quercus stem to the neighboring stem $(n=553)$. At the plot level, Pearson correlations were used to assess the relationship of percent of full sunlight, number of small-sized Quercus stems per quadrat and number of primary nearest neighbors per quadrat. Analyses of plot-level correlations were performed at three spatial resolutions $(5 \times 5 \mathrm{~m}, 10 \times 10 \mathrm{~m}$, and $20 \times 20 \mathrm{~m})$. To test for differences in competitive ability, species were pooled into three taxonomic groups (Quercus, A. saccharum, and O. virginiana) and then group of "others". Competition indices were analyzed using a $4 \times 4$ factorial ANOVA, with one factor being disturbance class (control, light, moderate, and severe classes) and one factor being the taxonomic groups (Quercus, A. saccharum, O. virginiana, and others), with Student-Newman-Keuls post-hoc test to determine which variables were significantly different $(p<0.01)$.

Geo-referenced maps were created and analyzed in ArcMap version 10.2 (Environmental Systems Research Institute, Redlands, CA, USA). Locations of small-sized Quercus stems, their primary nearest neighbors (other Quercus species, A. saccharum, and O. virginiana), and percent full sunlight were mapped, visually assessed, and then spatially analyzed with Global Moran's I to determine spatial dependence [78]. Acer rubrum was not a primary nearest neighbor, but was a species of interest (i.e., part of the "Quercus-to-Acer" transition) therefore it was also analyzed to determine its spatial dependence. Getis-Ord Gi* was used to find the extent to which each feature was surrounded by similar high or low values to determine patterns of distribution (i.e., clusters; [79]. All spatial data were examined at three resolutions: $5 \times 5 \mathrm{~m}, 10 \times 10 \mathrm{~m}$, and $20 \times 20 \mathrm{~m}$, to observe how patterns changed across spatial scale.

\section{Results}

\subsection{Structure and Composition}

Basal area of all live stems $\geqslant 5 \mathrm{~cm}$ within the plot was $20.6 \mathrm{~m}^{2} \cdot \mathrm{ha}^{-1}$ (Table 1 ). The five most dominant species based on basal area were Q. alba, F. grandifolia, O. virginiana, A. saccharum, and Carya ovata (Mill.) K. Koch. The species with the highest densities were O. virginiana, Q. alba, A. saccharum, F. grandifolia, and Cornus florida L. The estimated basal area lost (removed by the wind disturbance event) was $5.9 \mathrm{~m}^{2} \cdot \mathrm{ha}^{-1}$ (ca. $22 \%$ of the pre-disturbance total). The most common species damaged based on relative densities of dead stems in decay class I were Q. alba and O. virginiana. Of the $8005 \times 5 \mathrm{~m}$ quadrats sampled, 206 quadrats contained one or more Quercus species: Q. alba, Q. rubra L., Q. prinus L., Q. muehlenbergii Engelm., and Q. falcata Michx. In total, we documented 606 Quercus individuals throughout the 2 ha study plot. Of these, 553 stems were between 0.5 and $5.5 \mathrm{~m}$ height (referred to as small-sized Quercus stems) and used for analyses of competition. In total, we documented 14,675 live saplings in the 2 ha plot that were between 0.5 and $5.5 \mathrm{~m}$ height. 
Table 1. Density, dominance, and importance (relative density + relative dominance) measures for all live stems $\geqslant 5 \mathrm{~cm}$ DBH in a Quercus dominated stand within the Sipsey Wilderness, Alabama. Species are ranked according to importance value.

\begin{tabular}{|c|c|c|c|c|c|}
\hline Species & $\begin{array}{c}\text { Density } \\
\left(\text { Stems ha }^{-1}\right)\end{array}$ & $\begin{array}{c}\text { Relative } \\
\text { Density (\%) }\end{array}$ & $\begin{array}{l}\text { Dominance } \\
\left(\mathrm{m}^{2} \cdot \mathbf{h a}^{-1}\right)\end{array}$ & $\begin{array}{c}\text { Relative } \\
\text { Dominance (\%) }\end{array}$ & $\begin{array}{c}\text { Importance } \\
\text { Value }\end{array}$ \\
\hline Quercus alba & 115.5 & 16.0 & 11.5 & 56.1 & 72.1 \\
\hline Ostrya virginiana & 280.0 & 38.8 & 1.4 & 6.6 & 45.5 \\
\hline Fagus grandifolia & 52.5 & 7.3 & 1.4 & 6.6 & 13.9 \\
\hline Acer saccharum & 60.0 & 8.3 & 1.0 & 5.1 & 13.4 \\
\hline Nyssa sylvatica & 32.5 & 4.5 & 0.4 & 1.7 & 6.2 \\
\hline Cornus florida & 32.5 & 4.5 & 0.1 & 0.7 & 5.2 \\
\hline Carya glabra & 15.0 & 2.1 & 0.5 & 2.7 & 4.7 \\
\hline Ulmus alata & 15.0 & 2.1 & 0.4 & 1.8 & 3.9 \\
\hline Fraxinus americana & 9.5 & 1.3 & 0.5 & 2.4 & 3.8 \\
\hline Carya tomentosa & 8.5 & 1.2 & 0.5 & 2.3 & 3.5 \\
\hline Carya ovata & 7.5 & 1.0 & 0.4 & 2.0 & 3.1 \\
\hline Quercus falcata & 3.0 & 0.4 & 0.4 & 2.1 & 2.5 \\
\hline Liriodendron tulipifera & 3.0 & 0.4 & 0.4 & 2.1 & 2.5 \\
\hline Ulmus rubra & 8.0 & 1.1 & 0.2 & 1.1 & 2.2 \\
\hline Pinus taeda & 2.0 & 0.3 & 0.4 & 2.0 & 2.2 \\
\hline Magnolia acuminata & 10.0 & 1.4 & 0.1 & 0.7 & 2.1 \\
\hline Acer rubrum & 9.0 & 1.2 & 0.1 & 0.3 & 1.5 \\
\hline Quercus prinus & 3.5 & 0.5 & 0.2 & 1.0 & 1.5 \\
\hline Viburnum rufidulum & 8.5 & 1.2 & 0.0 & 0.1 & 1.3 \\
\hline Quercus muehlenbergii & 3.5 & 0.5 & 0.2 & 0.8 & 1.3 \\
\hline Cercis canadensis & 7.5 & 1.0 & 0.0 & 0.1 & 1.2 \\
\hline Carpinus caroliniana & 7.0 & 1.0 & 0.0 & 0.2 & 1.1 \\
\hline Juniperus virginiana & 4.5 & 0.6 & 0.1 & 0.4 & 1.0 \\
\hline Magnolia macrophylla & 5.0 & 0.7 & 0.0 & 0.2 & 0.8 \\
\hline Tilia americana & 4.5 & 0.6 & 0.0 & 0.2 & 0.8 \\
\hline Fraxinus pennsylvanica & 3.0 & 0.4 & 0.1 & 0.3 & 0.7 \\
\hline Oxydendrum arboreum & 2.0 & 0.3 & 0.0 & 0.1 & 0.4 \\
\hline Quercus rubra & 1.5 & 0.2 & 0.0 & 0.2 & 0.4 \\
\hline Prunus serotina & 2.0 & 0.3 & 0.0 & 0.1 & 0.3 \\
\hline Ilex opaca & 1.5 & 0.2 & 0.0 & 0.1 & 0.3 \\
\hline Frangula caroliniana & 1.0 & 0.1 & 0.0 & 0.0 & 0.2 \\
\hline Asimina triloba & 1.0 & 0.1 & 0.0 & 0.0 & 0.1 \\
\hline Quercus stellata & 0.5 & 0.1 & 0.0 & 0.0 & 0.1 \\
\hline Celtis laevigata & 0.5 & 0.1 & 0.0 & 0.0 & 0.1 \\
\hline Ligustrum sinense & 0.5 & 0.1 & 0.0 & 0.0 & 0.1 \\
\hline Total & 721 & 100.0 & 20.6 & 100.0 & 200.0 \\
\hline
\end{tabular}

\subsection{Quercus Advanced Reproduction and Competition}

The average height of the 553 small-sized Quercus stems inventoried in our plot was $1.33 \pm 0.80 \mathrm{~m}$ (SD; Table 2). The nearest neighbors between 0.5 and $5.5 \mathrm{~m}$ height to the focal Quercus stems represented 37 species. The average height of the nearest neighbor (competitor) stems was $1.70 \pm 0.98 \mathrm{~m}(\mathrm{SD})$. Average height of Quercus stems and average height of nearest neighboring stems (including Quercus neighbors) was significantly different $(p<0.01)$. Correlation between competitor height and Quercus stem height revealed a significant positive relationship $(p<0.01 ; r=0.39)$. The mean distance from a small-sized Quercus stem and its competing stem in the same size range was $0.32 \pm 0.25 \mathrm{~m}$ (SD). Correlation between competitor height and distance between the two competing stems revealed a significant positive relationship $(p<0.01 ; r=0.26)$. 
Table 2. Heights (mean \pm SD) of all Quercus stems (0.5-5.5 $\mathrm{m}$ in height), the nearest competing stem (0.5-5.5 $\mathrm{m}$ in height), and the distance (mean $\pm \mathrm{SD}$ ) between Quercus stems and their nearest competitor in a Quercus dominated stand within the Sipsey Wilderness, Alabama.

\begin{tabular}{ccccc}
\hline Species & $\boldsymbol{n}$ & $\begin{array}{c}\text { Quercus Stem } \\
\text { Height }(\mathbf{m})\end{array}$ & $\begin{array}{c}\text { Competitor Stem } \\
\text { Height }(\mathbf{m})\end{array}$ & $\begin{array}{c}\text { Distance between } \\
\text { Stems }(\mathbf{m})\end{array}$ \\
\hline Q. rubra & 231 & $1.38 \pm 0.83$ & $1.78 \pm 1.00$ & $0.36 \pm 0.23$ \\
Q. muhlenbergii & 190 & $1.47 \pm 0.72$ & $1.77 \pm 0.90$ & $0.28 \pm 0.27$ \\
Q. alba & 111 & $1.11 \pm 0.83$ & $1.53 \pm 1.05$ & $0.29 \pm 0.22$ \\
Q. prinus & 13 & $0.78 \pm 0.33$ & $1.19 \pm 0.69$ & $0.46 \pm 0.37$ \\
Q. facalta & 8 & $0.64 \pm 0.20$ & $1.07 \pm 0.63$ & $0.43 \pm 0.24$ \\
\hline Total & 553 & $1.33 \pm 0.80$ & $1.70 \pm 0.98$ & $0.33 \pm 0.25$ \\
\hline
\end{tabular}

At the genus level, Quercus was the most common nearest neighbor to the focal small-sized Quercus stems (35\% of all nearest neighbors were Quercus spp.). The most frequent interspecific competitors were A. saccharum (14\%), O. virginiana (12\%), Fraxinus americana L. (5\%), and Carpinus caroliniana Walt. (4\%). Of all instances when the nearest neighbor was a non-Quercus stem, $69 \%$ of the neighbors were taller than the focal Quercus stem. The mean distance between Quercus stems and interspecific competitors was $0.39 \pm 0.24 \mathrm{~m}$ (SD), whereas Quercus stems and intrageneric competitors were separated by a mean distance of $0.20 \pm 0.22 \mathrm{~m}$ (SD). Average distances between interspecific and intrageneric competitors were significantly different $(p<0.01)$.

Relative competitive ability was measured using the Hegyi (1974) competitor index which uses the height of each competitor tree to the subject tree (Quercus stem) and distance between competing trees. The moderate disturbance class had the highest average competitive index $(\mathrm{CI}=14.48)$ and the control neighborhood had the lowest average competitive index $(\mathrm{CI}=8.41)$, but competitive ability did not vary significantly $(p<0.05)$ by disturbance classes. With the exception of $O$. virginiana and the "other" group, competitive ability was significantly different $(p<0.05)$ between the taxonomic groups (Figure 2). Quercus exhibited the greatest competitive ability $(\mathrm{CI}=22.4)$ compared to the other species in all disturbance classes. Our results did not reveal significant interactions $(p<0.05)$ between the four disturbance classes and the four taxonomic groups. Quercus stems were consistently the strongest competitors in the control neighborhood and all disturbance class neighborhoods. Stems in the "other" group were the second most competitive in all disturbance class neighborhoods, but not the control neighborhood. Acer saccharum exhibited a higher competitive index in the light and moderate disturbance class neighborhoods, whereas $O$. virginiana exhibited a higher competitive index in the control neighborhood and the severe disturbance class neighborhood.

\subsection{Disturbance and Patterns of Irradiance}

Percent full sunlight and basal area removed were significantly correlated $(p<0.01 ; r=0.53)$ at the $20 \times 20 \mathrm{~m}$ resolution (i.e., the scale in which disturbance severity was classified). All disturbance neighborhoods had varying magnitudes of damage, which caused an array of irradiance levels ranging from $0.4 \%$ to $91.0 \%$ full sunlight (Figure 3). Average percent full sunlight was $4.8 \% \pm 2.2 \%$ (SD), $8.4 \% \pm 2.7 \%$ (SD), $10.8 \% \pm 2.9 \%$ (SD), $14.4 \% \pm 3.6 \%$ (SD) for the control neighborhood and the light, moderate, and severe disturbances class neighborhoods, respectively. Percent full sunlight was significantly different $(p<0.05)$ between the control neighborhood and light disturbance class neighborhood, the control neighborhood and moderate disturbance class neighborhood, and the control neighborhood and severe disturbance class neighborhood. 


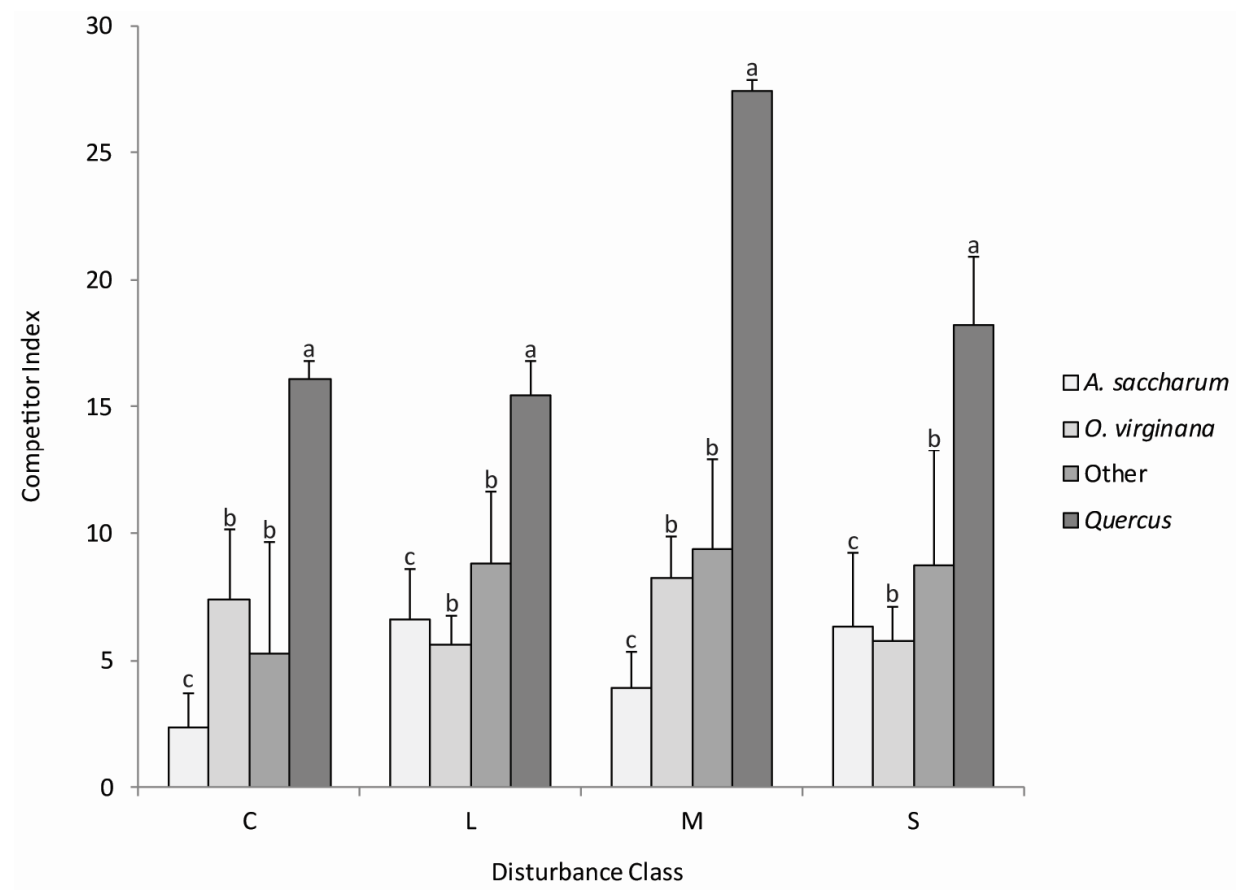

Figure 2. Average competitor indices with standard errors for competitor species $(0.5-5.5 \mathrm{~m}$ height by taxonomic group in the control neighborhood (C), and light (L), moderate (M) and severe (S) disturbance class neighborhoods. Bars with different lowercase letters within taxonomic groups represent significant differences $(p<0.05)$ among species competitive ability. CI did not vary significantly $(p<0.05)$ by disturbance classes.
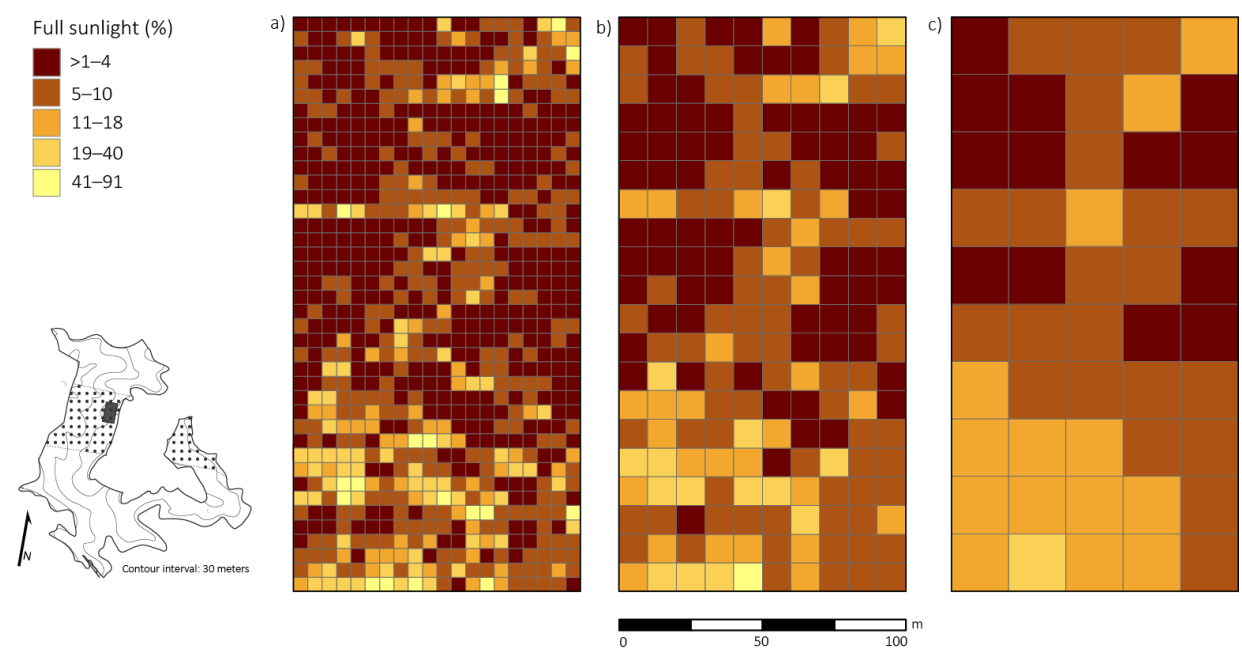

Figure 3. Spatial distribution of percent full sunlight taken at $1.47 \mathrm{~m}$ above the ground across a 2 ha plot four years after canopy disturbance in a Quercus dominated stand within the Sipsey Wilderness, Alabama, USA. Inset map shows the Quercus stand boundary, tornado swath (dotted pattern), plot location, and topography. (a) $5 \times 5 \mathrm{~m}$; (b) $10 \times 10 \mathrm{~m}$; (c) $20 \times 20 \mathrm{~m}$. See Figure 1 for disturbance class delineations.

Analysis at $5 \times 5 \mathrm{~m}$ resolution revealed a significant positive relationship $(p<0.01)$ between percent full sunlight and density of small-sized Quercus stems, but correlation strength was low $(r=0.26)$. At the $5 \times 5 \mathrm{~m}$ scale, we did not find a significant relationship $(p>0.01 ; r=0.003)$ between competition index and percent full sunlight values. At $10 \times 10 \mathrm{~m}$ and $20 \times 20 \mathrm{~m}$ resolutions, percent 
full sunlight and density of small-sized Quercus stems had stronger significant relationships $(p<0.05$, $r=0.39 ; p<0.05, r=0.60$, respectively). Also, at $10 \times 10 \mathrm{~m}$ and $20 \times 20 \mathrm{~m}$ resolutions, density of small-sized Quercus stems and basal area removed were significantly correlated $(p<0.01, r=0.24$; $p<0.01, r=0.52$, respectively).

Significant clustering of PAR (i.e., high values of percent full sunlight that were surrounded by similarly high values) was evident at all spatial scales tested: $5 \times 5 \mathrm{~m}, 10 \times 10 \mathrm{~m}, 20 \times 20 \mathrm{~m},(p<0.05$; $z=14.21$ ). Small-sized Quercus stem clusters overlapped and were in close proximity (i.e., $5 \mathrm{~m}$ radius from edge of Quercus clusters) with high values of percent full sunlight in multiple patches of moderate and severe disturbance neighborhoods (Figure 4). Acer rubrum only had one cluster $\left(25 \mathrm{~m}^{2}\right)$ that corresponded with high light levels. For the primary competitors, A. saccharum and O. virginiana, only two quadrats $\left(50 \mathrm{~m}^{2}\right)$ of high clustering for each species corresponded with high clustering of light levels. The spatial variability of primary competitors was lost at scales of $10 \times 10 \mathrm{~m}$ and $20 \times 20 \mathrm{~m}$. Thus, clusters of competitors that were detected at coarser resolutions did not correspond to clusters of high light levels.
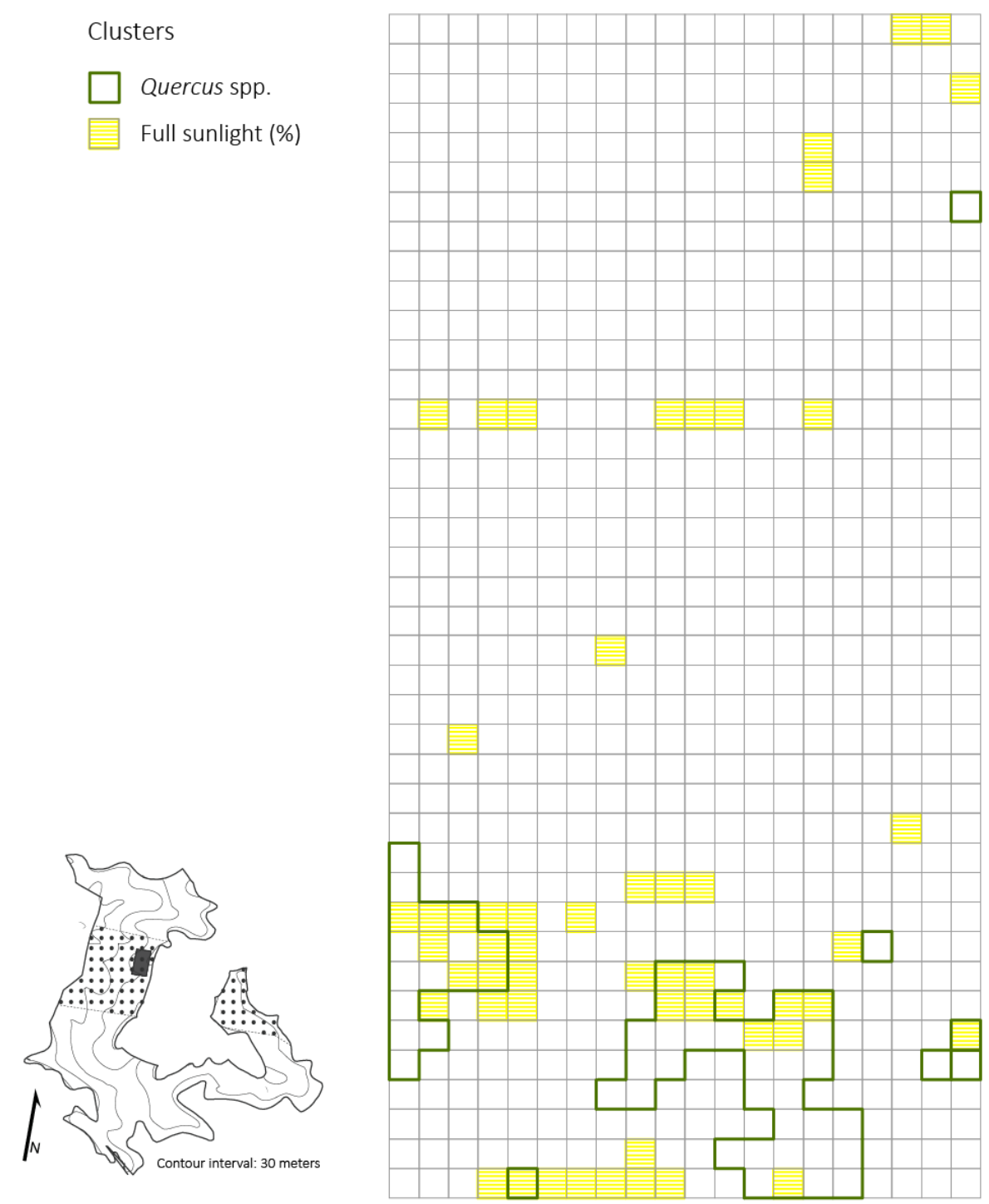

Figure 4. Distributions of Quercus spp. clusters and high light clusters based on percent of full sunlight across the 2 ha plot $(5 \times 5 \mathrm{~m}$ resolution) four years after the disturbance in a Quercus dominated stand within the Sipsey Wilderness, Alabama. Inset map shows the Quercus stand boundary, tornado swath (dotted pattern), plot location, and topography. See Figure 1 for disturbance class delineations. 


\subsection{Spatial Patterns of Advanced Reproduction}

Density of small-sized Quercus stems varied across all disturbance classes, and densities were highest in the moderate and severe disturbance class neighborhoods. The density of small-sized Quercus stems in the control neighborhood ( 0.1 stems per quadrat) was significantly different $(p<0.05)$ from the moderate (1.2 stems per quadrat) and severe (3.7 stems per quadrat) disturbance class neighborhoods. The density of small-sized Quercus stems in the severe disturbance class neighborhood was significantly greater $(p<0.05)$ than the density in all other categories. The density of $O$. virginiana stems $(0.5-5.5 \mathrm{~m}$ height $)$ did not significantly differ $(p>0.05)$ by disturbance class. The density of A. saccharum significantly differed $(p<0.05)$ between the moderate disturbance ( 3.4 stems per quadrat) and control class (1.3 stems per quadrat) neighborhoods and between the moderate disturbance and light disturbance class (1.7 stems per quadrat) neighborhoods.

At the $5 \times 5 \mathrm{~m}$ spatial resolution, densities of small-sized Quercus stems exhibited a significantly $(p<0.05 ; z=20.7)$ clustered distribution (i.e., contiguous quadrats with high Quercus stem density; cluster size: $1425 \mathrm{~m}^{2}$ ) in the moderate and severe disturbance neighborhoods (Figure 5). Ostrya virginiana $(p<0.05, z=17.41)$ and A. saccharum $(p<0.05, z=17.59)$ also exhibited significantly clustered distributions with total cluster sizes of $1350 \mathrm{~m}^{2}$ and $1,400 \mathrm{~m}^{2}$, respectively. Throughout the 2 ha plot, O. virginiana clusters were found in every disturbance class and the largest clusters $\left(375-550 \mathrm{~m}^{2}\right)$ occurred in the light and moderate disturbance classes. Acer saccharum clusters were found in the control neighborhood and the light and moderate disturbance class neighborhoods and the largest clusters $\left(350-375 \mathrm{~m}^{2}\right)$ were located where damage was classed as light or moderate. The one large A. rubrum cluster $\left(1075 \mathrm{~m}^{2}\right)$ was juxtaposed with the largest clusters of Quercus spp. (425-850 $\left.\mathrm{m}^{2}\right), O$. virginiana, and A. saccharum. Within moderate and severe disturbance class neighborhoods, there was little overlap of Quercus clusters and A. saccharum and O. virginiana clusters (Figure 6). The largest Quercus clusters occurred adjacent to and between the four major clusters of A. saccharum and O. virginiana. Correlations between the number of Quercus stems compared to $O$. virginiana and A. saccharum stems across the plot were negligible $(r=0.013 ; r=0.18)$.
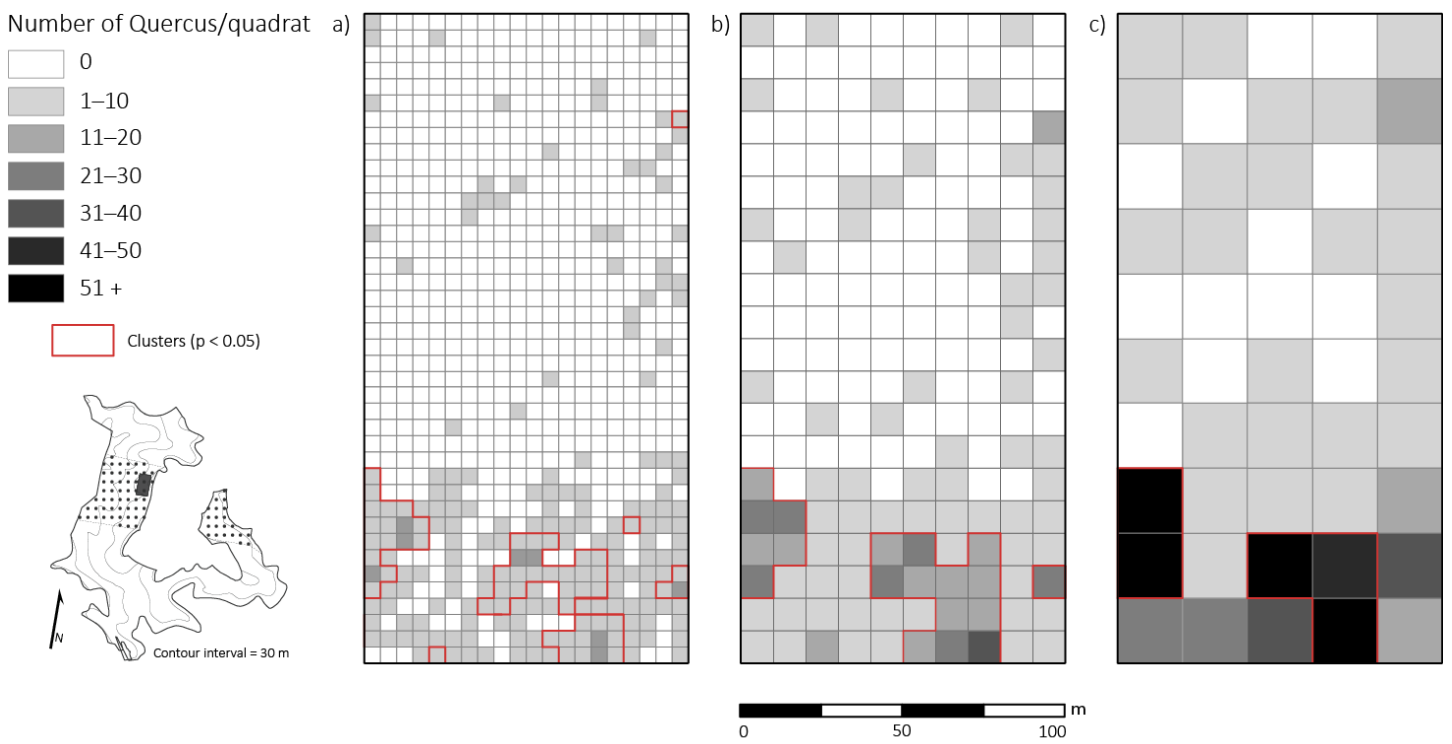

Figure 5. Distribution of small-sized Quercus stems across a 2 ha plot four years after canopy disturbance in a Quercus dominated stand within the Sipsey Wilderness, Alabama, USA. The red outlines represent the significant clustering $(p<0.05)$ of small-sized Quercus stems. Inset map shows the Quercus stand boundary, tornado swath (dotted pattern), plot location, and topography. (a) $5 \times 5 \mathrm{~m}$; (b) $10 \times 10 \mathrm{~m}$; (c) $20 \times 20 \mathrm{~m}$. See Figure 1 for disturbance class delineations. 
Clusters

Quercus spp.

A. saccharum

O. virginiana

A. rubrum
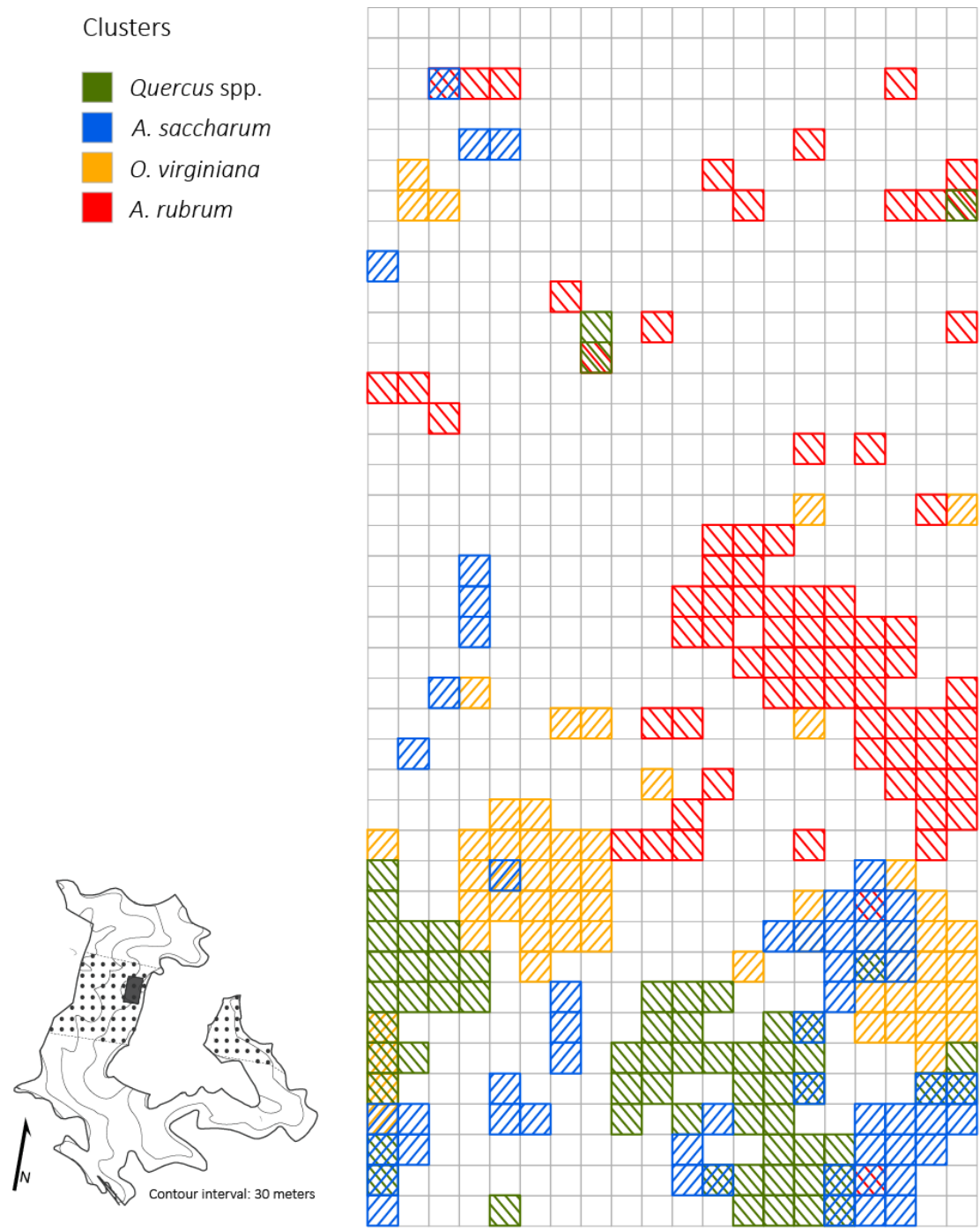

Figure 6. Distributions of Quercus spp., A. saccharum, O. virginiana, and A. rubrum clusters across a 2 ha plot ( $5 \times 5 \mathrm{~m}$ resolution) four years after canopy disturbance in a Quercus dominated stand within the Sipsey Wilderness, Alabama, USA. Inset map shows the Quercus stand boundary, tornado swath (dotted pattern), plot location, and topography. See Figure 1 for disturbance class delineations.

At the $10 \times 10 \mathrm{~m}$ resolution, each of the four taxa (Quercus, A. saccharum, O. virginiana, and A. rubrum) analyzed exhibited a clustered distribution throughout the 2 ha plot. Significant clusters $(p<0.05 ; z<1.96)$ were still present, but at lower spatial resolutions some clusters were no longer detectable. For Quercus spp., three clusters $\left(25 \mathrm{~m}^{2}\right.$ in size) were undetectable when scaling from the $5 \times 5 \mathrm{~m}$ resolution to the $10 \times 10 \mathrm{~m}$ resolution. Clusters of $O$. virginiana were only detected in the control neighborhood and the light and moderate disturbance class neighborhoods. Acer saccharum and $A$. rubrum clusters were still detectable in the control neighborhood and the light and moderate disturbance classes as they had been at the $5 \times 5 \mathrm{~m}$ scale. Correlations between the number of Quercus stems compared to A. saccharum stems across the plot became significantly positive $(p<0.01 ; r=0.24)$ at this spatial scale.

At the $20 \times 20 \mathrm{~m}$ resolution, clustered distributions were still significant $(p<0.05 ; z<1.96)$. One Quercus spp. cluster $\left(100 \mathrm{~m}^{2}\right.$ in area with 23 Quercus stems at the $10 \times 10 \mathrm{~m}$ resolution) was lost at this broad scale. Multiple A. saccharum and A. rubrum clusters were lost at coarser resolutions as well. Acer saccharum clusters were only detected in neighborhoods of light and moderate disturbance and A. rubrum was detected in the control neighborhood and light disturbance class neighborhood. 
Correlations between the number of small-sized Quercus stems compared to $A$. saccharum stems had the strongest positive relationship $(p<0.01 ; r=0.35)$ at the $20 \times 20 \mathrm{~m}$ scale.

\section{Discussion}

\subsection{Quercus Advanced Reproduction and Competition}

A stem's competitiveness can be described as the ability to avoid or endure suppression and is accounted for by the proximity of a focal tree to competitors and the relative size of the stems. Indeed, distance between competing stems plays a major role in the survival outcome of individuals. The closer the neighboring stems are to each other, the likelihood of the stem with the competitive advantage to overtop the adjacent stem increases. Lockhart et al. [70] provided results on the spacing of Quercus pagoda Raf. and interspecific competition, reporting that distances less than $1.8 \mathrm{~m}$ between stems could result in overtopping by the interspecific stem. The most distant stems in our study were just $1.45 \mathrm{~m}$ apart, so we posit that all small-sized Quercus stems we documented were exposed to some form of direct competition.

Heygi's [73] competition index is based on the assumption that neighboring tree size and proximity are the primary drivers of competition, so that relatively large stems in relatively close proximity exert more competitive influence relative to smaller stems at wider spacings. The most common nearest neighbors to the focal Quercus stems were other Quercus species (i.e., intrageneric competition). Intrageneric competition may be exceptionally strong because the individuals have similar resource requirements, growth rates, and root/crown habits [80]. The "other" taxonomic group and O. virginiana were the most competitive after Quercus and these taxonomic classes had similar competitive abilities. Ostrya virginiana lacks the potential to ascend into upper canopy strata, and has formed a "recalcitrant understory layer" [62,81], as the abundance of $O$. virginiana in the understory is likely inhibiting Quercus recruitment. Interestingly, Acer saccharum stems were the least competitive against small-sized Quercus stems. Acer saccharum saplings and small trees were abundant in our study plot, and were common throughout this and adjacent stands [60,62,63]. However, A. saccharum and Quercus were spatially segregated in the regeneration layer and as such were not commonly direct competitors. Although competitive ability significantly differed between taxonomic groups, it did not vary between disturbance classes. The modified conditions caused by the disturbance did not appear to alter competitiveness in the regeneration layer.

\subsection{Disturbance and Patterns of Irradiance}

Wind disturbance events typically remove overstory trees; understory strata are usually undisturbed except for areas impacted by fallen tree crowns or uplifted root networks of damaged trees [63,82]. During the fourth growing season post-disturbance, gaps in the main forest canopy were still prominent. However, within the disturbed neighborhoods, high density patches of advanced reproduction and midstory stems inhibited insolation from reaching strata near the forest floor. Indeed, irradiance measures at $1.37 \mathrm{~m}$ above the surface in some disturbed and undisturbed neighborhoods were similar. Thus, light levels in the regeneration layer had returned to pre-disturbance conditions for some neighborhoods in our plot. Other studies on natural and anthropogenic intermediate-scale canopy disturbances in Quercus stands in this region have found light levels to return to pre-disturbance conditions within three years of the disturbance event, based on the response of understory stems that were established prior to the event $[62,83]$.

Although Quercus at the genus level are considered moderately tolerant of shade, most are ultimately dependent on canopy disturbance to recruit into higher vertical strata [84,85]. The canopy openings (based on basal area removal) created by the disturbance were positively correlated with percent full sunlight; therefore, the increased irradiance generally followed the spatial pattern of the disturbance gradient. The gaps resulted in increasing light levels that were adequate (i.e., $20 \%-50 \%$ full sunlight) for Quercus advanced regeneration to recruit to larger size classes, but rapid growth 
of the shoot can only occur if the individual has a well-developed root system [36,67]. Small-sized Quercus stem density was positively correlated with canopy openings and percent full sunlight at the quadrat scale. We speculate the disturbance allowed Quercus seedlings present at the time of the event to recruit to our $0.5 \mathrm{~m}$ height threshold. Thus, we suggest that the post-disturbance conditions were favorable to understory and midstory Quercus stems. Furthermore, the density of small-sized Quercus stems increased in accord with disturbance severity and thus, insolation levels in our plot.

\subsection{Spatial Patterns of Advanced Reproduction}

Spatial dependence is often caused by underlying spatial processes that result in strong localized association among variables, and subsequently, cause clustering of similar values amongst these variables [86]. In our study, the intermediate-scale event removed $22 \%$ of the basal area within the 2 ha plot and created a fine-scale mosaic of varying levels of damage in a matrix of an undisturbed stand. Resultant openings in the canopy offered contrasting levels of light, temperature, and available soil moisture, and ultimately, increased the abundance and diversity of stems in the understory. Tree species in the understory differ in their ability to capture the newly available growing space created by the canopy gaps. Quercus spp. have a conservative regeneration technique that is usually disadvantageous when competing with species which have a more exploitive regeneration strategy [3]. Thus, the small-sized Quercus stems that recruited to larger size classes did so in locations where the potential for competitive ability was greater.

Relative stem density and average heights of Quercus stems increased with increasing canopy disturbance severity (i.e., from the control neighborhood to the severe disturbance neighborhood), indicating the variation of irradiance post-disturbance had a positive influence on Quercus recruitment, but a positive influence on non-Quercus individuals as well. Our results illustrate the need for managers who wish to maintain Quercus to combine overstory release treatments with some practice of controlling competing species that promotes the relative competitiveness of Quercus. The density of primary competitors did not increase linearly with increasing canopy disturbance severity. Acer saccharum had the highest density in the moderate disturbance class neighborhood and O. virginiana had the highest density in the severe disturbance neighborhood. Acer saccharum, F. grandifolia, and species that typically lack the potential to ascend into upper levels of the canopy, such as O. virginiana, effectively formed a "recalcitrant understory layer". High densities of $O$. virginiana have been reported in other studies conducted in the Sipsey Wilderness $[62,63]$ and although the species lacks the ability to be a true canopy dominant, its abundance in the regeneration layer was likely inhibiting Quercus recruitment. Interestingly, A. rubrum, which is a major component of the Quercus-to-Acer transition across the eastern USA, was not a primary competitor although it is abundant on the Bankhead National Forest [57].

The largest patches of small-sized Quercus stems in the moderate and severe disturbance neighborhoods indicated post-disturbance environmental conditions were favorable for Quercus spp. Broadening the scale (i.e., $5 \times 5 \mathrm{~m}$ to $10 \times 10 \mathrm{~m}$ or $10 \times 10 \mathrm{~m}$ to $20 \times 20 \mathrm{~m}$ ) caused spatial variability to be lost amongst small-sized Quercus stems. As spatial scale broadened, clusters covered a larger area but small-sized Quercus stem densities stayed similar to those found at finer resolutions (e.g., fine-scale analysis revealed a $425 \mathrm{~m}^{2}$ cluster with 108 stems and broad-scale analysis revealed an $800 \mathrm{~m}^{2}$ cluster with 116 stems). At the $20 \times 20 \mathrm{~m}$ scale, areas that did not contain small-sized Quercus stems were incorporated into the clusters. Therefore, the $5 \times 5 \mathrm{~m}$ scale was the best to identify Quercus clusters. We suggest this is because analysis of individual stems of advanced regeneration in gaps is a fine-scale process [87].

Clusters of competitor species were larger than the identified clusters of the small-sized Quercus stems. We posited that competitors (i.e., non-Quercus) were able to compete effectively over larger areas than Quercus spp. The highest densities of competitor species occurred in the moderate and severe disturbance class neighborhoods, but these taxa occurred throughout the entire plot. We speculate for A. saccharum and O. virginiana, environmental gradients were probably the primary influence of clustering across the plot, despite their constitutive presence through the whole plot. Although these 
competitors have low light compensation points relative to Quercus spp., they certainly benefited from the growing space made available by the canopy disturbance.

\section{Conclusions}

In some Quercus stands that are successional to more shade-tolerant species, managers might consider treatments that address intra-stand heterogeneity, such as variable retention harvesting and group selection methods, to promote Quercus regeneration. Indeed, approaches that promote within-stand variability are becoming increasingly popular. In such successional Quercus stands, patches of Quercus advanced reproduction may serve as nuclei to maintain and spatially expand zones within which Quercus is regenerating. These focal areas should be explicitly considered when developing a silvicultural prescription designed to maintain the Quercus component in successional stands.

Acknowledgments: This research was funded as a Joint Venture Agreement between the Northern Research Station, USDA Forest Service and the University of Alabama. We thank Win Cowden, Lauren Cox, and Cindy Taylor for assistance in the field, the Bankhead National Forest staff for logistical support, and Michael Steinberg and Lauren Cox for comments on prior drafts of the manuscript.

Author Contributions: Amanda M. Keasberry and Justin L. Hart conceived and designed the study; Amanda M. Keasberry led the field work and analyzed the data; Amanda M. Keasberry, Justin L. Hart, Daniel C. Dey, and Callie J. Schweitzer wrote the paper.

Conflicts of Interest: The authors declare no conflicts of interests.

\section{References}

1. Hogan, C. Oak, 2012. Available online: http://www.eoearth.org/view/article/161730 (accessed on 15 March 2015).

2. Dyer, J.M. Revisiting the deciduous forests of eastern North America. Bioscience 2006, 56, 341-352. [CrossRef]

3. Johnson, P.S.; Shifley, S.R.; Rogers, R. The Ecology and Silviculture of Oaks, 2nd ed.; CABI Publishing: New York, NY, USA, 2009.

4. Smith, W.B.; Miles, P.D.; Perry, C.H.; Pugh, S.A. Forest Resources of the United States, 2007; General Technical Report WO-78; USDA Forest Service: Washington, DC, USA, 2009.

5. Delcourt, H.R. Late Quaternary vegetation history of the Eastern Highland Rim and adjacent Cumberland Plateau of Tennessee. Ecol. Monogr. 1979, 49, 255-280. [CrossRef]

6. Delcourt, H.R.; Delcourt, P.A. Eastern deciduous forests. In North American Terrestrial Vegetation, 2nd ed.; Barbour, M.G., Billings, D.W., Eds.; Cambridge University Press: Cambridge, UK, 2000; Chapter 10.

7. Abrams, M.D. The postglacial history of oak forests in eastern North America. In Oak Forest Systems Ecology and Management for Wildlife; McShea, W.J., Healy, W.M., Eds.; John Hopkins University Press: Baltimore, MD, USA, 2002; pp. 34-45.

8. Fei, S.; Steiner, K.C. Evidence for increasing red maple abundance in the eastern United States. For. Sci. 2007, 53, 473-477.

9. Nowacki, G.J.; Abrams, M.D. The demise of fire and "mesophication" of forest in the eastern United States. Bioscience 2008, 58, 123-138. [CrossRef]

10. Fei, S.; Kong, N.; Steiner, K.C.; Moser, W.K.; Steiner, E.B. Change in oak abundance in the eastern United States from 1980 to 2008. For. Ecol. Manag. 2011, 255, 2297-2305. [CrossRef]

11. Watt, A.S. On the natural cause of failure of regeneration in British oak woods. J. Ecol. 1919, 17, $173-203$. [CrossRef]

12. Shaw, M.W. Factors affecting the natural regeneration of sessile oak (Quercus petraea) in north Wales. J. Ecol. 1968, 56, 565-583. [CrossRef]

13. Li, Q.; Ma, K. Factors affecting establishment of Quercus liaotungensis Koidz. under mature mixed oak forest overstory and in shrubland. For. Ecol. Manag. 2003, 176, 133-146. [CrossRef]

14. Esteso-Martinez, J.; Camarero, J.J.; Gil-Pelegrin, E. Competitive effects of herbs on Quercus faginea seedlings inferred from vulnerability curves and spatial-pattern analyses in a Mediterranean stand (Iberian System, northeast Spain). Ecoscience 2006, 13, 378-387. [CrossRef] 
15. Hanberry, B.B. Changing eastern broadleaf, southern mixed, and northern mixed forest ecosystems of the eastern United States. For. Ecol. Manag. 2013, 306, 171-178. [CrossRef]

16. Abrams, M.D. Fire and the development of oak forests. Bioscience 1992, 42, 346-353. [CrossRef]

17. Abrams, M.D. Prescribing fire in eastern oak forests: Is time running out? North. J. Appl. For. 2005, 22, 190-196.

18. McEwan, R.W.; Dyer, J.M.; Pederson, N. Multiple interacting ecosystem drivers: Toward an encompassing hypothesis of oak forest dynamics across eastern North America. Ecography 2011, 34, 224-256. [CrossRef]

19. McShea, W.J.; Healy, W.M.; Devers, P.; Fearer, T.; Koch, F.H.; Stauffer, D.; Waldon, J. Forestry matters: Decline of oaks will impact wildlife in hardwood forests. J. Wildl. Manag. 2007, 71, 1717-1728. [CrossRef]

20. Alexander, D.C.; Arthur, M.A. Implications of a predicted shift from upland oaks to red maple on forest hydrology and nutrient availability. Can. J. For. Res. 2010, 40, 716-726. [CrossRef]

21. Dey, D.C. Sustaining oak forests in eastern North America: Regeneration and recruitment, the pillars of sustainability. For. Sci. 2014, 60, 926-942. [CrossRef]

22. Lorimer, C.G. Development of the red maple understory in northeastern oak forests. For. Sci. 1984, 30, 3-22.

23. Abrams, M.D.; Nowacki, G.J. Historical variation in fire, oak recruitment and post-logging accelerated succession in central Pennsylvania. Bull. Torrey Bot. Club 1992, 119, 19-25. [CrossRef]

24. McGee, C.E.; Loftis, D.L. Oak regeneration: A summary. Oak Regeneration: Serious Problems, Practical Recommendations; General Technical Report SE-84; Loftis, D.L., McGee, C.E., Eds.; USDA Forest Service Southeastern Forest Experiment Station: Asheville, NC, USA, 1993; pp. 316-319.

25. Lorimer, C.G. Causes of the oak regeneration problem. In Oak Regeneration: Serious Problems, Practical Recommendations; General Technical Report SE-84; Loftis, D.L., McGee, C.E., Eds.; USDA Forest Service Southeastern Forest Experiment Station: Asheville, NC, USA, 1993; pp. 14-39.

26. Smith, D.W. Oak regeneration: The scope of the problem. In Oak Regeneration: Serious Problems, Practical Recommendations; General Technical Report SE-84; Loftis, D.L., McGee, C.E., Eds.; USDA Forest Service Southeastern Forest Experiment Station: Asheville, NC, USA, 1993; pp. 40-52.

27. Crow, T.R. Reproductive mode and mechanisms for self-replacement of northern red oak (Quercus rubra) —A review. For. Sci. 1988, 34, 19-40.

28. Abrams, M.D.; Downs, J.A. Successional replacement of old-growth white oak by mixed mesophytic hardwoods in southwest Pennsylvania. Can. J. For. Res. 1990, 20, 1864-1870. [CrossRef]

29. Nowacki, G.J.; Abrams, M.D.; Lorimer, C.G. Composition, structure, and historical development of northern red oak stands along an edaphic gradient in north-central Wisconsin. For. Sci. 1990, 36, 276-292.

30. Abrams, M.D. Where has all the white oak gone? Bioscience 2003, 53, 927-939. [CrossRef]

31. Abrams, M.D. The red maple paradox. Bioscience 1998, 45, 355-363. [CrossRef]

32. Fei, S.; Steiner, K.C. Rapid capture of growing space by red maple. Can. J. For. Res. 2009, 39, 1444-1452. [CrossRef]

33. Hart, J.L.; Clark, S.L.; Torreano, S.J.; Buchanan, M.L. Composition, structure, and dendroecology of an old-growth Quercus forest on the tablelands of the Cumberland Plateau, USA. For. Ecol. Manag. 2012, 266, 11-24. [CrossRef]

34. Johnson, P.S. Thinking about oak forests as responsive ecosystems. Upland Oak Ecology Symposium: History Current Conditions, and Sustainability; Gen. Tech. Rep. SRS-73; Spetich, M.A., Ed.; U.S.D.A. Forest Service, Southern Research Station: Asheville, NC, USA, 2004; pp. 13-18.

35. Gottschalk, K.W. Management strategies for successful regeneration: Oak-hickory. In Proceedings of the Forestry Issues Conference, University Park, PA, USA, 15-16 March 1983; pp. 190-213.

36. Dey, D.C. The ecological basis for oak silviculture in eastern North America. In Oak Forest Ecosystems; McShea, W.J., Healy, W.M., Eds.; John Hopkins University Press: Baltimore, MD, USA, 2002; pp. 46-60.

37. Rogers, R. Spatial Pattern and Growth in a Missouri Oak-Hickory Stand. Ph.D. Dissertation, University of Missouri, Columbia, MO, USA, 1983.

38. O'Hara, K.L.; Nagel, L.M. The stand: Revisiting a central concept in forestry. J. For. 2013, 111, 335-340.

39. Puettman, K.J.; Coates, D.K.; Messier, C. A Critique of Silviculture: Managing for Complexity; Island Press: Washington, DC, USA, 2009.

40. Churchill, D.C.; Larson, A.J.; Dalhgreen, M.C.; Franklin, J.F.; Hessburg, P.F.; Lutz, J.A. Restoring forest resilience: From reference spatial patterns to silvicultural prescriptions and monitoring. For. Ecol. Manag. 2013, 291, 442-457. [CrossRef] 
41. Runkle, J.R. Disturbance regimes in temperate forests. In The Ecology of Natural Disturbance and Patch Dynamics; Pickett, S.T.A., White, P.S., Eds.; Academic Press: San Diego, CA, USA, 1985; pp. 17-33.

42. White, P.S.; Pickett, S.T.A. Natural disturbance and patch dynamics: An introduction. In The Ecology of Natural Disturbance and Patch Dynamics; Pickett, S.T.A., White, P.S., Eds.; Academic Press: San Diego, CA, USA, 1985; pp. 3-13.

43. Canham, C.D.; Papaik, M.J.; Latty, E.F. Interspecific variation in susceptibility to windthrow as a function of tree size and storm severity for northern temperate tree species. Can. J. For. Res. 2001, 31, 1-10. [CrossRef]

44. Hanson, J.J.; Lorimer, C.G. Forest structure and light regimes following moderate wind storms: Implications for multi-cohort management. Ecol. Appl. 2007, 17, 1325-1340. [CrossRef] [PubMed]

45. Hart, J.L.; Kupfer, J.A. Sapling richness and composition in canopy gaps of a southern Appalachian mixed Quercus forest. J. Torrey Bot. Soc. 2011, 138, 207-219. [CrossRef]

46. Wiens, J.A. Spatial scaling in ecology. Funct. Ecol. 1989, 3, 385-397. [CrossRef]

47. Fenneman, N.M. Physiography of Eastern United States; McGraw-Hill Book Company: New York, NY, USA, 1938.

48. Smalley, G.W. Classification and Evaluation for Forest Sites on the Southern Cumberland Plateau; General Technical Report SO-23; USDA, Forest Service, Southern Forest Experiment Station: New Orleans, LA, USA, 1979.

49. Szabo, M.W.; Osborne, E.W.; Copeland, C.W., Jr.; Neathery, T.L. Geologic Map of Alabama, Special Map 220 Scale 1:250,000; Geological Survey of Alabama: Tuscaloosa, AL, USA, 1988.

50. USDA SCS (United Stated Department of Agriculture, Soil Conservation Service). Soil Survey: Lawrence County, AL; Series 1949, No. 10. Government Printing Office: Washington, DC, USA, 1959.

51. Thornthwaite, C.W. An approach toward rational classification of climate. Geogr. Rev. 1948, 38, 55-94. [CrossRef]

52. PRISM Climate Group. Northwest Alliance for Computational Science and Engineering. Available online: http:/ / www.prism.oregonstate.edu/ (accessed on 3 March 2011).

53. Burt, C.C.; Stroud, M. Extreme Weather: A Guide and Record Book; W.W. Norton \& Company: New York, NY, USA, 2007.

54. Braun, E.L. Eastern Deciduous Forests of North America; Blakiston: Philadelphia, PA, USA, 1950.

55. Hinkle, C.R. Forest communities of the Cumberland Plateau of Tennessee. J. Tenn. Acad. Sci. 1989, 64, 123-129.

56. Clatterbuck, W.K.; Smalley, G.W.; Turner, J.A.; Travis, A. Natural History and Land Use History of Cumberland Plateau Forests in Tennessee; Special Report 06-01; National Council for Air and Stream Improvement, Inc.: Research Triangle Park, NC, USA, 2006; p. 37.

57. Zhang, L.; Oswald, B.P.; Green, T.H. Relationships between overstory species and community classification of the Sipsey Wilderness, Alabama. For. Ecol. Manag. 1999, 114, 377-383. [CrossRef]

58. Parker, R.P.; Hart, J.L. Patterns of riparian and in-stream large woody debris across a chronosequence of southern Appalachian hardwood stands. Nat. Areas J. 2014, 34, 65-78. [CrossRef]

59. Hardin, D.E.; Lewis, K.P. Vegetation analysis of Bee Branch Gorge, a hemlock beech community of the Warrior River Basin of Alabama. Castanea 1980, 45, 248-256.

60. Richards, J.D.; Hart, J.L. Canopy gap dynamics and development patterns in secondary Quercus stands on the Cumberland Plateau, Alabama, USA. For. Ecol. Manag. 2011, 262, 2229-2239. [CrossRef]

61. National Weather Service (NWS). Birmingham, AL Weather Forecast Office, 2011. Available online: http:/ / www.srh.noaa.gov/bmx/?n=event_04202011 (accessed on 1 April 2015).

62. Cowden, M.C.; Hart, J.L.; Schweitzer, C.J.; Dey, D.C. Effects of intermediate-scale wind disturbance on composition, structure, and succession in Quercus stands: Implications for natural disturbance-based silviculture. For. Ecol. Manag. 2014, 330, 240-251. [CrossRef]

63. White, S.D.; Hart, J.L.; Schweitzer, C.J.; Dey, D.C. Altered structural development and accelerated succession from intermediate-scale wind disturbance in Quercus stands on the Cumberland Plateau, USA. For. Ecol. Manag. 2015, 336, 52-64. [CrossRef]

64. NCDC (National Climate Data Center). Tornado Climatology, NOAA, 2013. Available online: http://www.ncdc.noaa.gov/oa/climate/severeweather/tornadoes.html (accessed on 1 March 2015).

65. Clinton, B.D.; Vose, J.M.; Swank, W.T. Site preparation burning to improve southern Appalachian pine-hardwood stands: Vegetation composition and diversity of 13-year-old stands. Can. J. For. Res. 1993, 23, 2271-2277. [CrossRef] 
66. Fraver, S.; Wagner, R.G.; Day, M. Dynamics of coarse woody debris following gap harvesting in the Acadian forest of central Maine, U.S.A. Can. J. For. Res. 2002, 32, 2094-2105. [CrossRef]

67. Sander, I.L. Size of Oak Reproduction: Key to Growth Following Harvest Cutting; USDA Forest Service Res. Pap. NC-97; North Central Experiment Station: St. Paul, MN, USA, 1972; p. 6.

68. Zenner, E.K.; Heggenstaller, D.J.; Brose, P.H.; Peck, J.E.; Steiner, K.C. Reconstructing the competitive dynamics of mixed-oak neighborhoods. Can. J. For. Res. 2012, 42, 1714-1723. [CrossRef]

69. Clatterbuck, W.K.; Hodges, J.D. Development of cherrybark oak and sweetgum in a mixed, even-aged bottomland stand in central Mississippi, USA. Can. J. For. Res. 1988, 18, 12-18. [CrossRef]

70. Lockhart, B.R.; Ezell, A.W.; Hodges, J.D.; Clatterbuck, W.K. Using natural stand development patterns in artificial mixtures: A case study with cherrybark oak and sweetgum in east-central Mississippi, USA. For. Ecol. Manag. 2006, 222, 202-210. [CrossRef]

71. Krajicek, J.E.; Brinkman, K.A.; Gingrich, S.F. Crown competition-a measure of density. For. Sci. 1961, 7, $35-42$.

72. Runkle, J.R. Patterns of disturbance in some old-growth mesic forests of eastern North America. Ecology 1982, 63, 1533-1546. [CrossRef]

73. Hegyi, F. A simulation model for managing jack-pine stands. In Growth Models for Tree and Stand Simulation; Fries, J., Ed.; Royal College of Forestry: Stockholm, Sweden, 1974; pp. 74-90.

74. Lorimer, C.G. Tests of age-independent competition indices for individual trees in natural hardwood stands. For. Ecol. Manag. 1983, 6, 343-360. [CrossRef]

75. Holmes, M.J.; Reed, D.D. Competition indices for mixed species northern hardwoods. For. Sci. 1991, 37, 1338-1349.

76. Cole, W.G.; Lorimer, C.G. Predicting tree growth from crown variables in managed Northern hardwood stands. For. Ecol. Manag. 1994, 67, 159-175. [CrossRef]

77. Weber, P.; Bugmann, H.; Fonti, P.; Rigling, A. Using a retrospective dynamic competition index to reconstruct forest succession. For. Ecol. Manag. 2008, 254, 96-106. [CrossRef]

78. Fu, W.J.; Jiang, P.K.; Zhou, G.M.; Zhao, K.L. Using Moran's I and GIS to study the spatial pattern of forest litter carbon density in a subtropical region of southeastern China. Biogeosciences 2014, 11, 2401-2409. [CrossRef]

79. Crain, B.J.; Tremblay, R.L. Do richness and rarity hotspots really matter for orchid conservation in light of anticipated habitat loss? Divers. Distrib. 2014, 20, 652-662. [CrossRef]

80. Tilman, D. Resource Competition and Community Structure; Princeton University Press: Princeton, NJ, USA, 1982.

81. Royo, A.A.; Carson, W.P. On the formation of dense understory layers in forests worldwide: Consequences and implications for forest dynamics, biodiversity, and succession. Can. J. For. Res. 2006, 36, 1345-1362. [CrossRef]

82. Peterson, C.J. Consistent influence of tree diameter and species on damage in nine eastern North American tornado blowdowns. For. Ecol. Manag. 2007, 250, 96-108. [CrossRef]

83. Schweitzer, C.J.; Dey, D.C. Forest structure, composition, and tree diversity response to a gradient of regeneration harvests in the mid-Cumberland Plateau escarpment region, USA. For. Ecol. Manag. 2011, 262, 1729-1741. [CrossRef]

84. Carvell, K.L.; Tryon, E.H. The effect of environmental factors on the abundance of oak regeneration beneath mature oak stands. For. Sci. 1961, 7, 98-105.

85. Dey, D.C.; Guyette, R.P. Anthropogenic fire history and red oak forests in south-central Ontario. For. Chronicle 2000, 76, 339-347. [CrossRef]

86. Zhang, L.; Ma, Z.; Guo, L. An evaluation of spatial autocorrelation and heterogeneity in the residuals of six regression models. For. Sci. 2009, 55, 533-548.

87. Zenner, E.K.; Sagheb-Talebi, K.; Akhavan, R.; Peck, J.E. Integration of small-scale canopy dynamics smoothes live-tree structural complexity across development stages in old-growth Oriental beech (Fagus orientalis Lipsky) forests at the multi-gap scale. For. Ecol. Manag. 2015, 335, 26-36. [CrossRef]

(C) 2016 by the authors; licensee MDPI, Basel, Switzerland. This article is an open access article distributed under the terms and conditions of the Creative Commons by Attribution (CC-BY) license (http://creativecommons.org/licenses/by/4.0/). 